\title{
EPIPHYTIC DIATOMS AND TROPHIC STATUS OF WATER ASSOCIATION IN SUEZ CANAL, GULF OF SUEZ AND RED SEA COAST OF EGYPT
}

\author{
Mohammed A. I. Deyab \\ Fac. of Science, Botany Dept., Damietta Univ., New Damietta, P.O. Box 34517.
}

\begin{abstract}
Seasonal physicochemical analysis of sea water and epiphytic diatoms at Suez Canal (3 sites), Gulf of Suez (3 sites) and Red Sea coast of Egypt (6 sites) indicated that nutritional status of water (nitrogen, phosphorus and silicon) decreased sharply downward (from Qantara to Marsa Alam). Meanwhile, the surface water salinity and water temperature increased. The total annual number of epiphytic diatom species decreased gradually from Qantara (48 species) towards El-Sharm ( 15 species). The most frequent diatom species belonging to genera Navicula, Cynedra, Achnanthes, Eunotia, Diatoma, Cocconeis, Cymbella, Licmophora, fragilaria, Amphora and Melosira. The maximum growth of epiphytic diatom (cell number and biomass) was recorded during summer, while the minimum during winter. A dendrogram of diatom communities resulted in five clusters according to temporal and trophic status of water. Water samples were mesoeutrophic at Ras Ghareib, Fayeid and Qantara during summer, with Generic Diatom Index (GDI) equals 11-12. Most water samples of cluster I and II were oligo-mesotrophic (GDIequals12-14) during spring and autumn. Oligotrophic water (GDI>14) were recorded in samples belongs to clusters IV and V while most samples are related to cluster III.
\end{abstract}

Key words: Epiphytic Diatoms, Eutrophication, Generic Diatom Index (G.D.I), Marine Water Quality, Multivariate Analysis.

\section{Introduction}

Red Sea is considered as one of the least affected areas by pollution in the world (Head, 1987). Pollution induced by anthropogenic activities including oil spills and excessive loading of nutrients through addition of fertilizers and industrial waste water and sewage have been reported (Abou-Aisha et al., 1995). Recently, the increase of agricultural activities especially drainage discharges into Suez Canal and tourist activities may play a considerable role in eutrophication and significant variation of water properties. Wastewater discharges cause variation of physicochemical characteristics of water (Adesalu et al., 2008). The Red Sea is a semi closed basin with no river inflow situated in an arid zone where evaporation greatly exceeds precipitation (Poisson $\boldsymbol{e t}$ al., 1984). Diatoms can provide reliable inferences of changes in solute delivery to the coastal ecosystem (Anna et al., 2010). 
Hassan et al. (2012) record 31 species belonging to 10 genera of epiphytic diatoms (Class: Bacillariophyceae) from Hawizah marshes (Iraq). Salinity and nutrient sources of nitrogen, phosphate and silicon were the important factors that impact the growth of epiphytic diatoms (Lai and Wang, 2010). Certain epiphytic diatoms grow in marine waters, where the solutes are usually 33-40 gm/L (Durai and Pandiyan, 2011). Epiphytic diatoms play an important role in marine communities contributing to primary productivity of ecosystems (Fatam and Tufan, 2010) supplying food for grazers (Tiina et al., 2010); evaluate the water quality (Juttner et al., 2010).

Moreover, it is believed that, biological factors may be important in determining epiphytic diatom distribution (Gordon $\boldsymbol{e t}$ al., 2007 and Lesley $\boldsymbol{e t}$ al., 2010). Multivariate analysis is useful to detect ecological information such as diatom species to environment association and species to species association (Katoh, 1991). Generic diatom index (GDI) used as a tool for estimating trophic status of sea water and for routine monitoring (Janina et al., 1998). This work aims to qualify the ecology of epiphytic diatoms and its uses to evaluate the trophic status of marine water as a response of increasing human impact on the Suez Canal, Suez Gulf and the Red Sea coast of Egypt.

\section{Materials and Methods}

Quarterly samples were collected seasonally according to hydrographic condition and degree of human impact on the sea (Fig. 1). These samples represent twelve sites (48 samples) along the west shore of Suez Canal (I-Qantara, II-Fayeid, III-Suez), Suez Gulf (3 sites) and the Red Sea coast of Egypt (6 sites) during spring, summer, autumn, 2009 and winter, 2010.

Physicochemical analysis of water as reactive phosphate nitrate-N, nitrite$\mathrm{N}$, ammonia $\mathrm{N}$, chloride, total alkalinity, total phosphorus, dissolved organic nitrogen and cations $(\mathrm{Na}, \mathrm{K})$ were analyzed according to Person and Strikland (1965). Water temperature, salinity and $\mathrm{pH}$ were measured by using S-C.T meter and $\mathrm{pH}$-meter. Biological oxygen demand (BOD), Reactive Silica and Dissolved oxygen (DO) measured according to EPA (1983). Total hardness was measured according to titration method (Adams, 1990).

For studying the epiphytic diatoms, about $100 \mathrm{~g}$ fresh weight of Laurancia obtusa (The most common seaweed at all sites) were collected twice each season. These samples were inserted in coke fit $500 \mathrm{ml}$ tubular degraded polyethylene bottle and preserved in $200 \mathrm{ml}$ of $4 \%$ formaldehyde solution for microscopic examination. The preserved samples were strongly shaken several times (about 15 times through $30 \mathrm{~min}$ ) and these processes were repeated every 6 hours overnight. The fragment of $L$. obtusa carefully removed from sampling bottle and inserted in new polyethylene bottle containing $100 \mathrm{ml}$ of $4 \%$ formaldehyde solution and strongly shaken 15 times through 15 minutes. This solution was added to sampling bottle. The L. obtusa fragment was washed 3 times. Ultimately, the sampling bottle contains $500 \mathrm{ml}$ of preserved solution with epiphytic diatoms. $5 \mathrm{ml}$ of 
formaldehyde were added in the bottle which covered by aluminum foil and carefully placed on laboratory bench for diatom settling through 72 hours. Supernatant was carefully siphoned by using very slow droplet system. I used micro tube (which covered by phytoplankton net) impeded slowly and carefully inside supernatant until $25 \mathrm{ml}$ degrade. After siphonation the epiphytic diatoms in $25 \mathrm{ml}, 4 \%$ formalin solution used for the qualitative analysis (Cronberg, 1982).

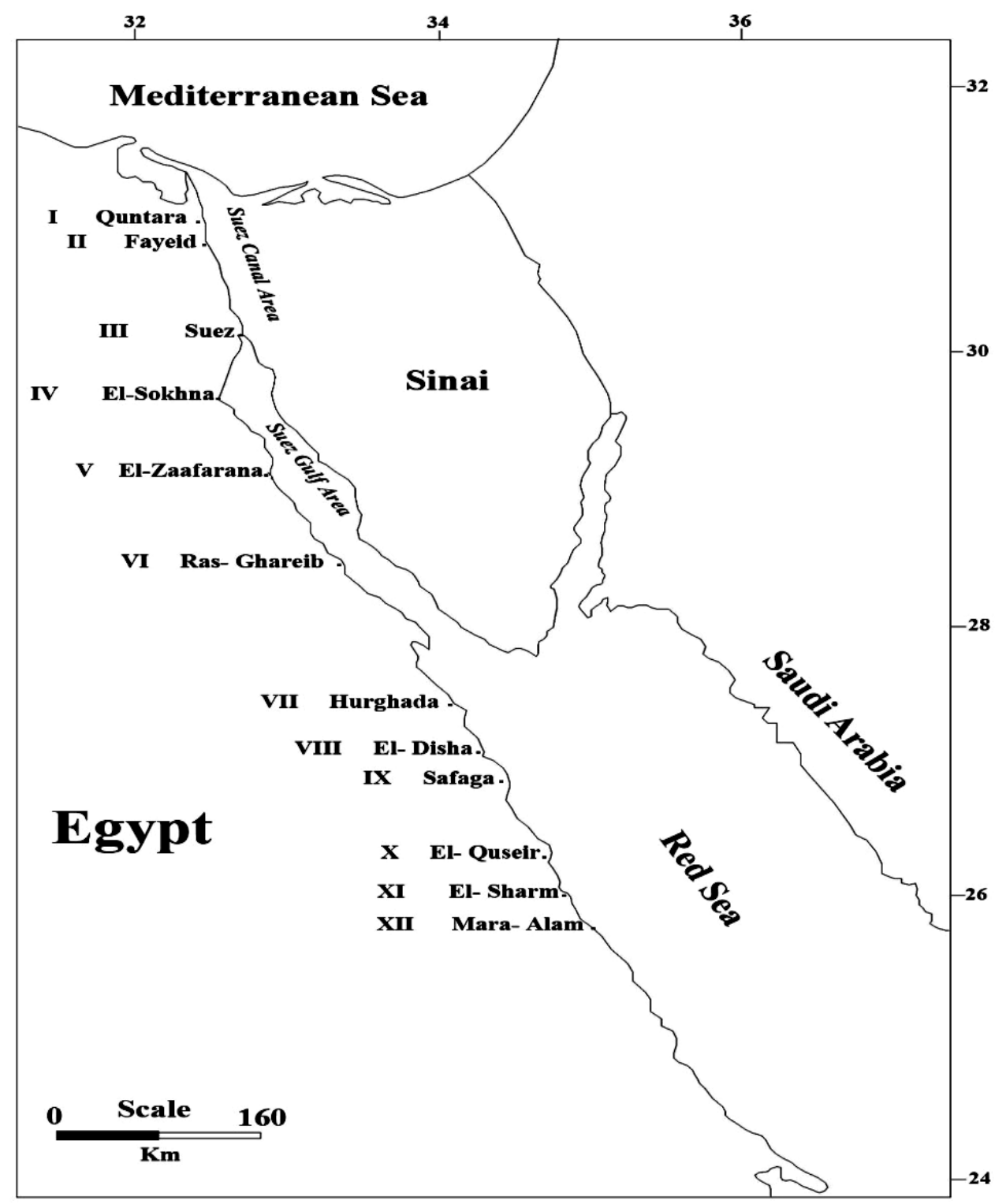

Figure (1): Study sites along the Suez Canal (3 sites), Suez Gulf (3 sites) and the Red Sea Coast of Egypt ( 6 sites). 
The preserved as well as fresh samples were examined microscopically for the identification of the different genera and species. It is necessary to have clean and clear diatom frustules to be identified easily. Therefore the following cleaning technique was adopted: $5 \mathrm{ml}$ of a concentrated sample were transferred into a $50 \mathrm{ml}$ beaker, $10 \mathrm{ml}$ of conc. $\mathrm{H}_{2} \mathrm{SO}_{4}$ were added and the mixture was heated gently. When the fumes of sulphoric acid started to appear, the beaker was covered with a Petri-dish. After complete charring of the sample, the beaker was removed and few drops of $\mathrm{H}_{2} \mathrm{O}_{2}$ were added until the sample became completely clear. The clear sample was repeatedly washed with distilled water followed by centrifugation till it became acid free. Three portions, each of $5 \mathrm{ml}$, from each sample were cleaned using the above mentioned technique and then the cleaned samples were examined microscopically for the identification. Generally, identification of algal taxa (species and varieties) was made according to Cupp (1943) and Krammer and Lange-Bertalot (1986-1991). The quantitative analysis occurred by a Sedwick-Rafter counting chamber (Ganf, 1974). Counting the number of each species in $0.1 \mathrm{ml}$ and consequently in $25 \mathrm{ml}$. According to the volume of each species its biomass can be calculated.

Statistical analysis: The seasonal diatom community results of each site were subjected to 'OMNIDIA' program (Lecointe et al., 1993) to calculate Generic Diatoms Index (GDI) according to Coste and Ayphassarho (1991).

GDI value for each sample (48 samples) was transformed to scale from 0 to 20 indicating the water quality range from hyper-eutrophic to oligotrophic. Diatoms community results were also processed using cluster analysis (Pearson Correlation and Average linkage methods) according to Clifford and Stephenson (1975) to compare the quality index values with the sets of the dominant taxa at each site. The results were also processed using Canonical Correspondence Analysis (CCA) to relate the distribution of epiphytic diatoms along the gradients of environmental variables (Ter Braak, 1987). One-way analyses of variance (ANOVA) were used to test any significant differences between a set of means of water variables representing the studied stations.

Correlation and regression: A2-tailed Pearson product moment correlation was performed using software program SPSS to examine the relationship between all physicochemical and biological parameters.

\section{Results and Discussion}

The values of water $\mathrm{pH}$ (7.55- 8.08) exhibited a narrow range of seasonal and local variation ( $\mathrm{p} \leq \square 0.05$ ). The variation in main annual water temperature paralleled with the climatic conditions in Egypt which increase southward) (Table1). Variations in water temperature affected the community composition of the marine algae (Trono and Tollentino, 1992). The relative low values of water salinity and high values of nitrite, nitrate, total phosphorous, orthophosphate and silica were recorded at site I, II and III (Table1). These findings are in contrast 
with that reported by Madkour (2000). This may be attributed to the newly constructed agricultural discharge stations at Suez Canal (about $100 \times 10^{3} \mathrm{~m}^{3} \cdot \mathrm{min}^{-1}$ ).

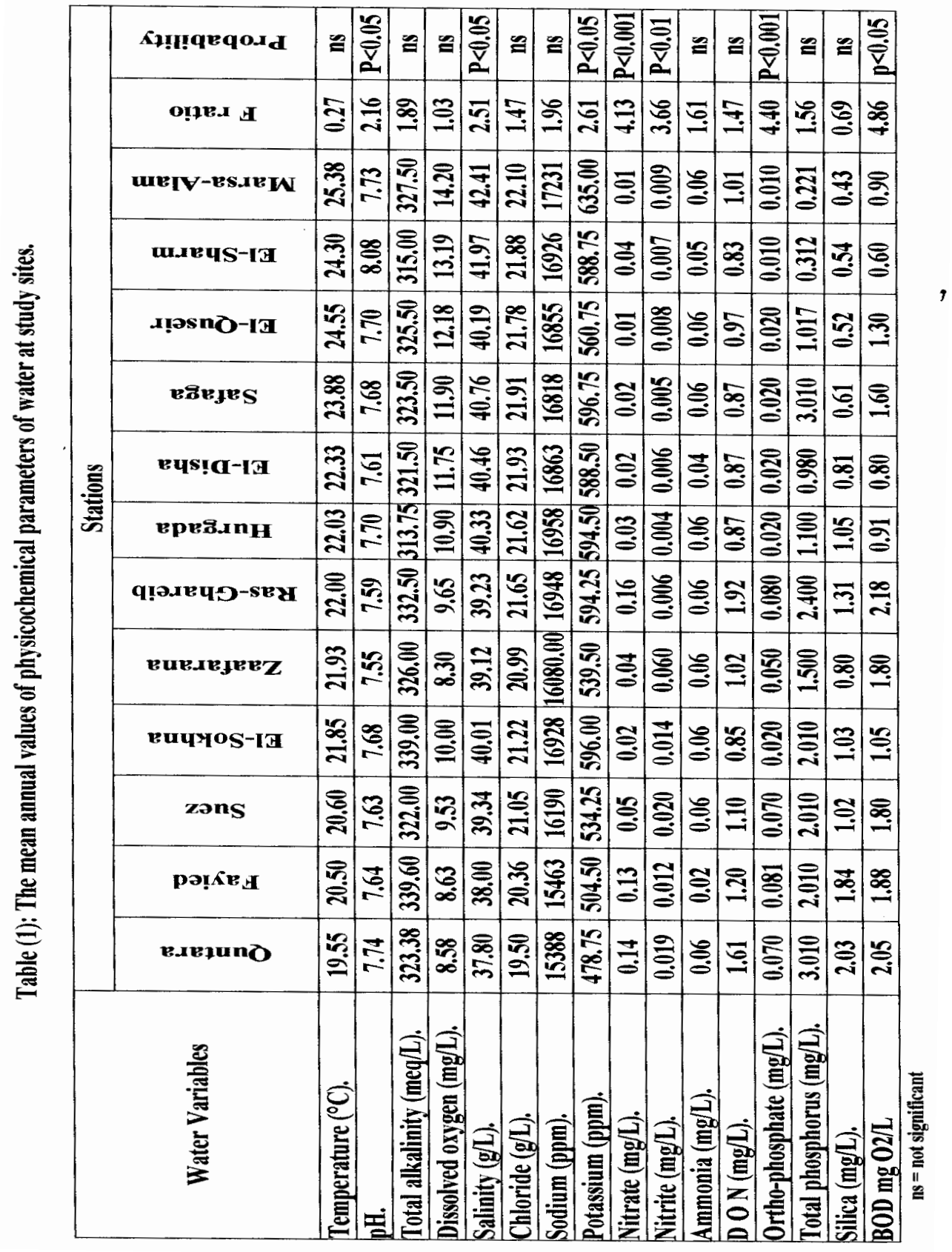


Domestic sewage discharged at site V and VI and the loading of raw phosphate on ships at site IX increasing total phosphorous contents of water. In this respect Adesalu et al. (2008) indicated that, an increase of nitrate-N concentration, $\mathrm{PO}_{4}{ }^{3-}$ and silica was due to a direct result of the agricultural runoff. The relative low annual mean values of dissolved oxygen(DO) content of water (8.3-9.8 $\mathrm{mg} \mathrm{O}_{2} / \mathrm{L}$ ) was recorded at stations I, II, III and VI, this may be related to the discharge of organic wastes, while the maximum annual main value of DO was recorded at El-Sharm (13.2 $\left.\mathrm{mg} \mathrm{O}_{2} / \mathrm{L}\right)$ and Marsa Alam (14.2 $\left.\mathrm{mg} \mathrm{O}_{2} / \mathrm{L}\right)$ stations probably because of water movement and without organic pollutants; these agreement with result detained by Tiina $\boldsymbol{e t}$ al. (2010). The significant increase of sewage and agricultural runoff resulted in the relative high value of Biological Oxygen Demand (BOD) at Suez Canal and Suez Gulf sites (Tab I), this agreement with the result detained by Abdel-Baky (2001).

The total annual number of epiphytic diatom species decreased gradually from Qantara (48 species) southward to the El-Sharm (15 species) (Fig. 2A). This paralleled mainly to the gradually increase of salinity; decrease of land run off and decrease of nutrient contents of water. IN this regard Cook (2007) reported that salinity affects the growth of marine algae. Moreover, Polat and Isik (2002) concluded that the increase in seawater nutrients is mainly due to the land run off; sewage wastes and vertical mixing process.

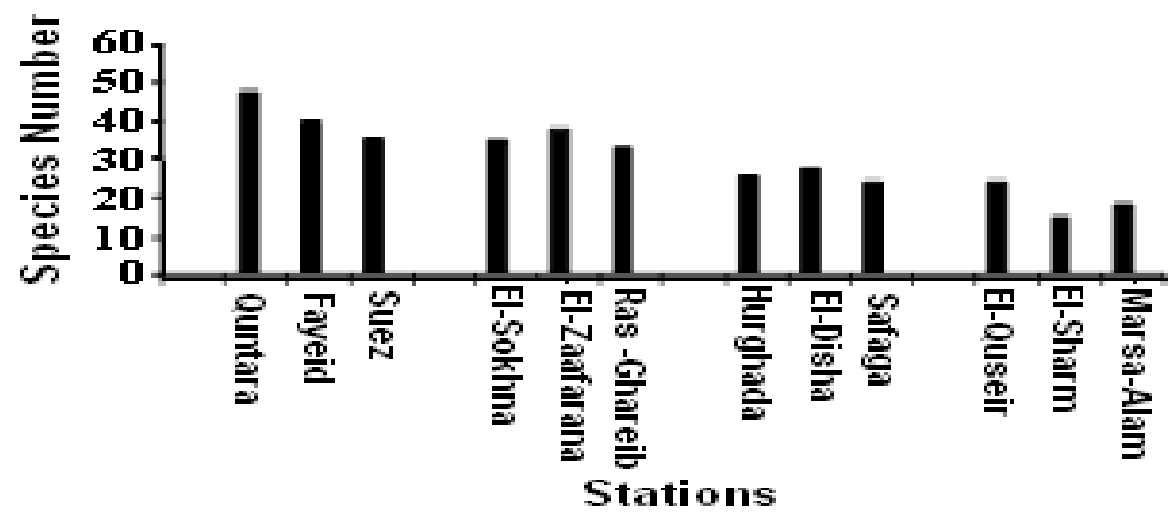

Figure (2A): The total annual number of the epiphytic diatom species at the studied sites along the Suez Canal, Suez Gulf and the Red Sea coast of Egypt.

Seasonally the highest epiphytic diatom number of species was recorded during summer in most stations, while it is low number recorded in winter (Fig. 2B). This may be related to the interaction between relative high content of water nutrients during summer and the epiphytic diatom species .In this respect, Elisabeth et al. (2003) reported that, there are a positive correlation between the epiphytic diatoms growth and the nutrient level in the marine water .Moreover, 
warm summer accelerate the biogeochemical cycle of nutrients in water especially for nitrogen, phosphorous and silica (Vis et al., 2006).

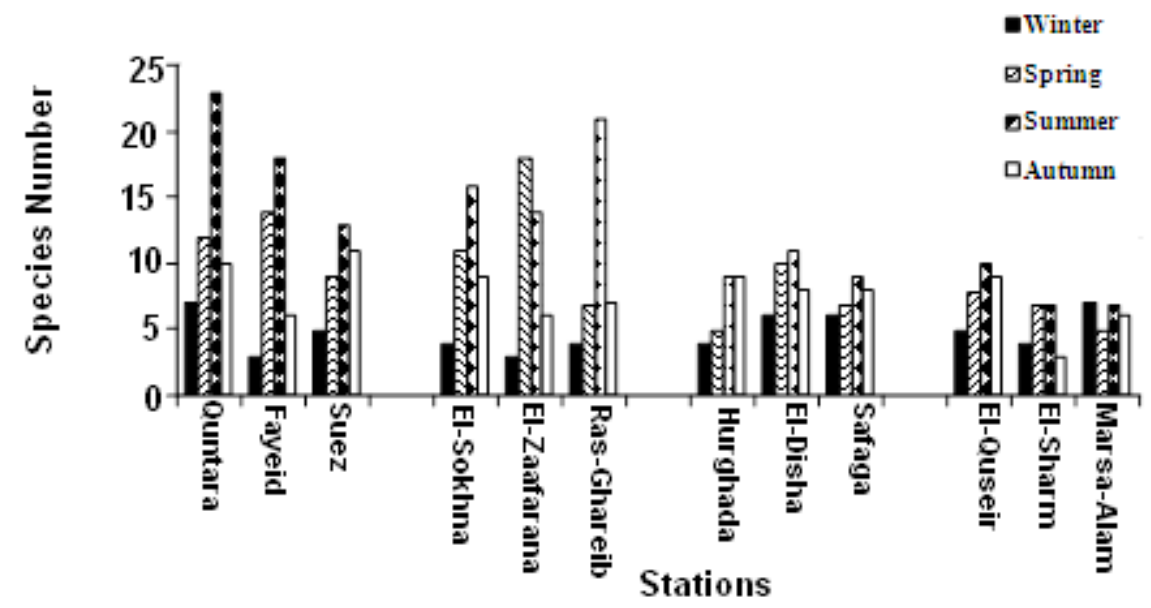

Figure (2B): The seasonal variation of the epiphytic diatom species number along the Suez Canal, Suez Gulf and the Red Sea coast of Egypt.

The highest total annual biomass of epiphytic diatoms recorded at Ras Ghareib (Fig. 3A). Seasonally its highest was recorded biomass at Fayeid during summer (Fig.3B); due to the relative high nitrate content of water. But significant low temperature and relative low salinity at Fayeid especially during spring, autumn and winter accelerate invertebrate grazing epiphytic diatoms and consequently the epiphytic diatoms biomass during these 3 seasons decreased. In this regard, Lesley et al. (2010) suggested that, effects of grazers to control epiphytic diatom biomass were stronger than the effects of nutrient enrichment.

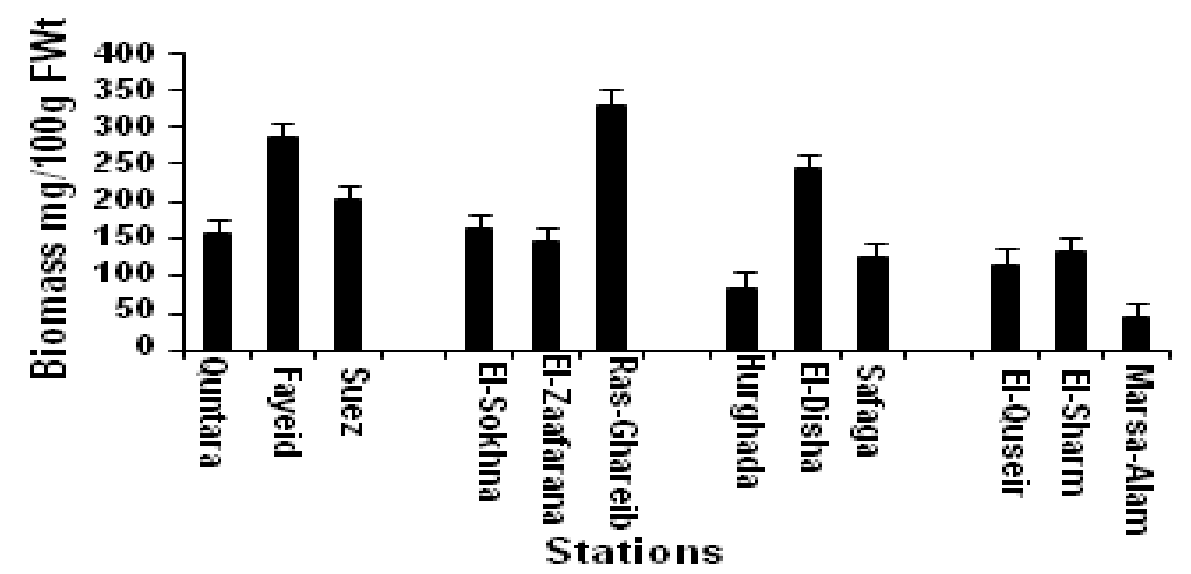

Figure (3A): The total annual biomass of the epiphytic diatoms (mg/100g FW) along the Suez Canal, Suez Gulf and the Red Sea coast of Egypt. 


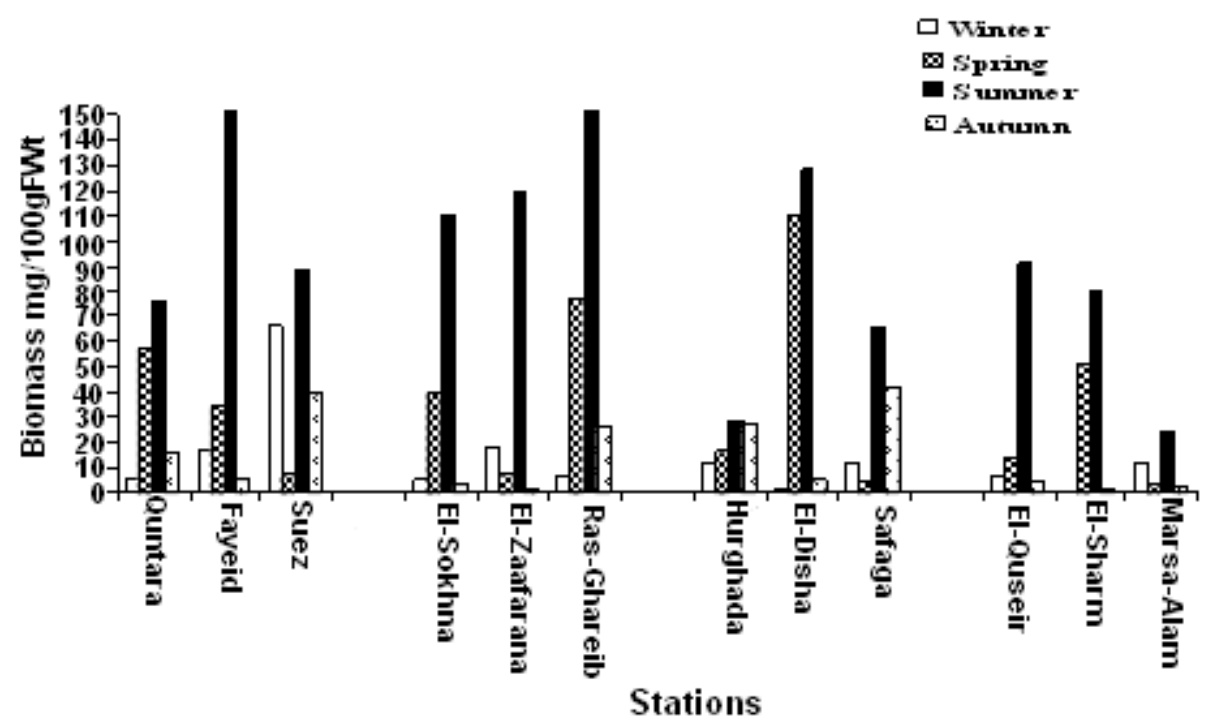

Figure (3 B): The seasonal variation of the epiphytic diatoms biomass $(\mathrm{mg} / 100 \mathrm{~g} \mathrm{FWt})$ along the Suez Canal, Suez Gulf and the Red Sea coast of Egypt.

Although there was considerable local variation of total annual biomass of epiphytic diatoms (Fig. 3A). Meanwhile the total annual standing crop (Cell Number) recorded a very little local variation at study area (Fig. 4A). These may be due to the differences of predominant diatom taxa at different sites.

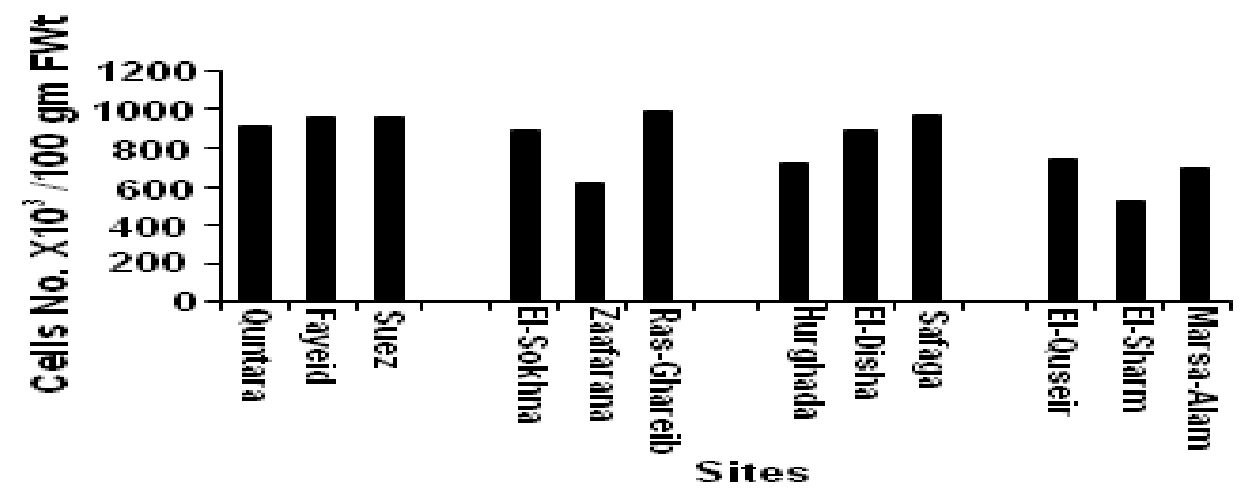

Figure (4A): The total annual epiphytic diatoms standing crop (Cell No. $X 10^{3} / 100$ gm FWt) at the studied sites along the Suez Canal, Suez Gulf and the Red Sea coast of Egypt.

Seasonally the highest cell number of epiphytic diatom was recorded during summer in most sites (Fig. 4B); while it is low cell number was recorded during winter. This may be related to the relative high content of water nutrient in 
summer induce diatom growth and reproduction, this agreement with Vis $\boldsymbol{e t}$ al. (2006).

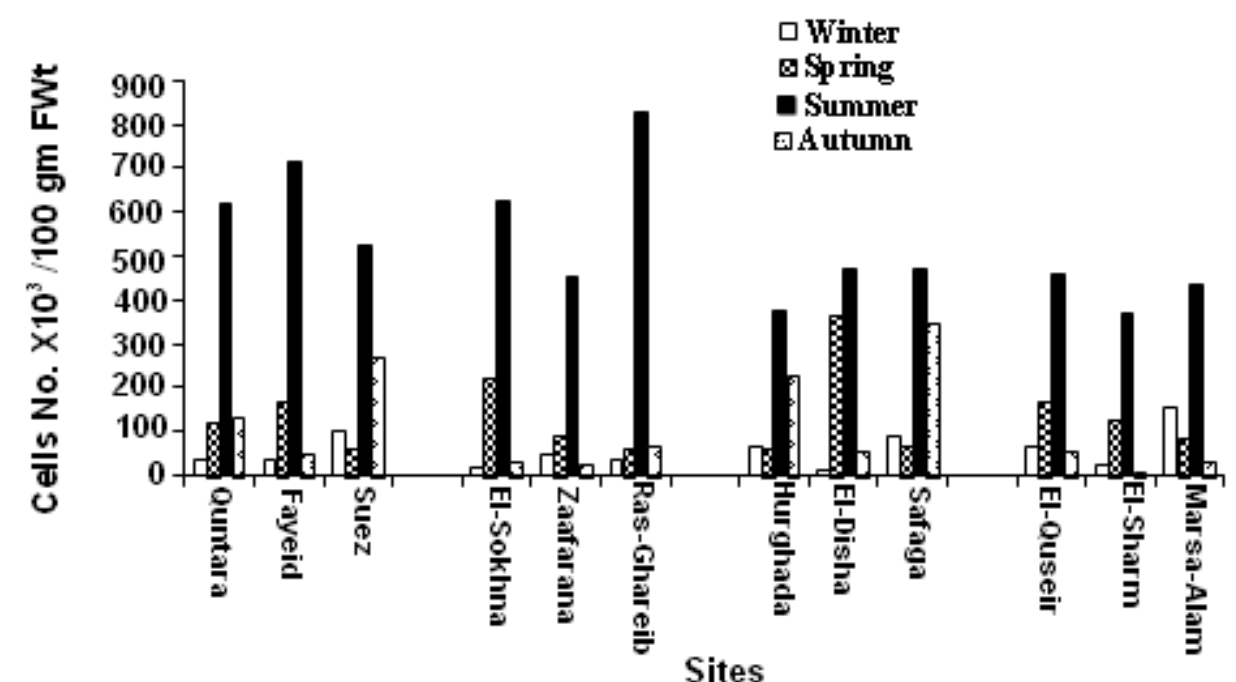

Figure (4B): The seasonal variations of epiphytic diatoms standing crop (Cells No. X $10^{3} / 100$ gm FWt) along the Suez Canal, Suez Gulf and the Red Sea coast of Egypt.

The relationships between the predominant epiphytic diatom species and water variables are shown in the ordination diagram that is produced by the canonical correspondence analysis (CCA) ordination (Fig. 5). Length of the variable expresses its relative importance, the longer the arrow the more important the variable.

Navicula microcephala, Fragilaria bicaputat and Fenestrata circulztis capucina were located at high position along the gradients of total phosphorus, silica, $\mathrm{pH}$, chloride, salinity, nitrite and temperature. Meanwhile, at low position along the gradients of ammonia, total alkalinity and nitrate concentration in winter. Navicula distans, Cocconeis thumensis var. diminuta, Gyrosigma scalpriodes, Melosira hyperborean and Nitzshia acicularis were located at high position along the gradients of dissolved oxygen. Ammonia, total alkalinity, $\mathrm{pH}$, total phosphorus and silica concentration in water while, at low position along the gradients of nitrate, salinity, sodium, temperature, potassium and dissolved organic nitrogen (DON) concentration in water, Synedra ulna was located at an intermediate position along the gradients of salinity, sodium, potassium, $\mathrm{pH}$, chloride, DON, temperature and total phosphorus concentration in water, and at high position along the gradients of ammonia and nitrate. Similarly, Melosria jeurgensii, Amphora veneta and Licmophora paradoxa were located at an intermediate position along the gradients of total alkalinity and dissolved oxygen, and at high position along the gradients of ammonia and nitrate concentration in 
water. But, at low position along the gradients of $\mathrm{pH}$, tot phosphorus, silica, sodium and salinity concentration in water Nitzschia longssima and Melosira islandica were located at low position along the gradients of dissolved oxygen, total alkalinity, ammonia, $\mathrm{pH}$, total phosphorus, silica, chloride, salinity and sodium concentration in water and at high position along the gradients of temperature, nitrate, DON, nitrate and potassium concentration in water.

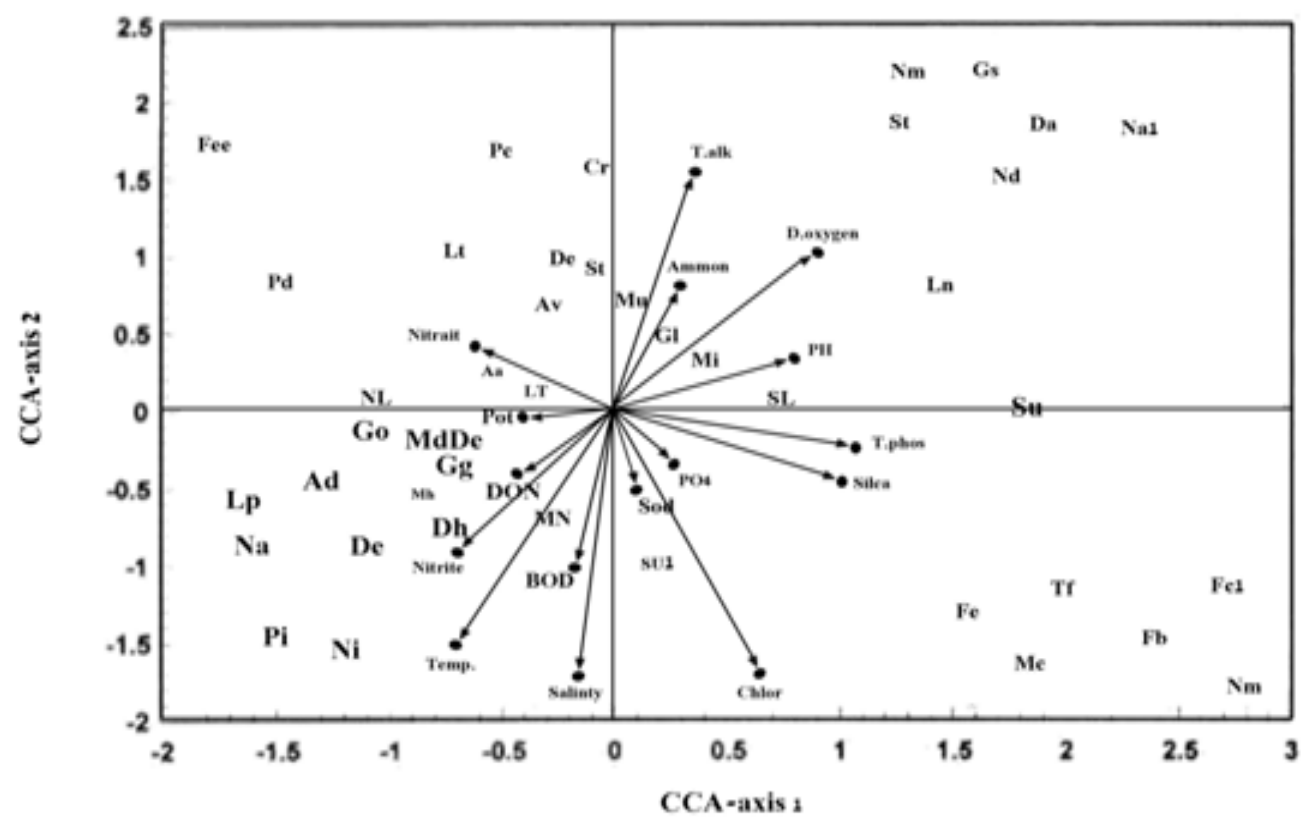

Figure (5): Canonical correspondence Analysis (CCA) ordination diagram of dominant epiphytic diatom species along the Red Sea coast of Egypt (Cross) with water variables (arrows) at the studied sites.

The indicator species are shown by the first letter of the genus and species names. Achnanthes lanceolata $=\mathrm{Al}$; Achnanthes affinis $=\mathrm{Aa} ;$ Amphora proteus $=\mathrm{Ap} ;$ Amphora veneta $=\mathrm{Av} ;$ Caloneis bacillum $=\mathrm{Cb} ;$ Calonies obtuse = Co; Cocconeis pediculus =Cp; C. thumensis = Ct; Cyclotella commenisis = Cc; Cymbella gracilis $=$ $\mathrm{Cg} ;$ Cymbelle tumidula $=\mathrm{Cyt} ;$ Diatoma elongatum $=\mathrm{De} ;$ Diatoma hiemale $=\mathrm{Dh} ;$ Eunotia lunaris $=\mathrm{El}$; Fragilaria bicapitata $=\mathrm{Fb} ;$ Fragilaria capucina $=\mathrm{Fc} ;$ Fragilaria crotonensis $=$ Fcr; Grommatophora oceanica $=$ Go; G. attenuatum = Ga; Gyrosigma scalproides = Gs; Licmophora comunis $=\mathrm{Lc} ;$ Lhyalina $=\mathrm{Lh} ;$ Licmophora paradoxa $=\mathrm{Lp} ;$ L. tenuis $=\mathrm{Lt} ;$ Melosira circular $=\mathrm{Mc} ;$ Melosira distans $=\mathrm{Md} ;$ Melosira hyperborean $=\mathrm{Mh} ;$ Melosira islandica $=\mathrm{Mi} ;$ Melosira undulata $=\mathrm{Mu} ;$ Navicula microcephala $=\mathrm{Nm} ;$ Navicula distans $=\mathrm{Nd}$; Navicula incerta $=\mathrm{Ni}$; Nitzschia closterium $=\mathrm{Nc} ;$ Nitzschia acicularis $=\mathrm{Na} ;$ Nitzschia longissima $=\mathrm{N} 1 ;$ Surirella linearis $=\mathrm{Sl}$; Synedra minuscula $=\mathrm{Sm} ;$ Synedra tabulata $=\mathrm{St} ;$ Synedra ulna $=\mathrm{Su} ;$ Tabellaria fenestrate $=\mathrm{Tf}$.

Synedra utermoehlii, Licmophora hyalina, Surirella linearis, Grammatophora oceanica, Melosira distans and Caloneis obtusa were located at high position along the gradients of potassium, nitrate, temperature, DON, nitrate, silica and salinity concentration water at low position along the gradients of total alkalinity, dissolved oxygen and ammonia concentration in water, and at an intermediate position along the gradients of chloride concentration in water. 
Limophora tennuis and Gyrosigma attenuatum were located at an intermediate position along the gradients of nitrate, temperature, salinity and chloride. While, at high position along the gradients of total phosphorus, sodium, (DON), biological oxygen demand (BOD), silica, $\mathrm{pH}$ and $\mathrm{O}$. phosphate concentration in water, and at low position along the gradients of dissolved oxygen, total alkalinity, ammonia and nitrate concentration in water.

There were 9 samples in cluster I; most of these samples were collected in spring season regardless sites (fig. 6).

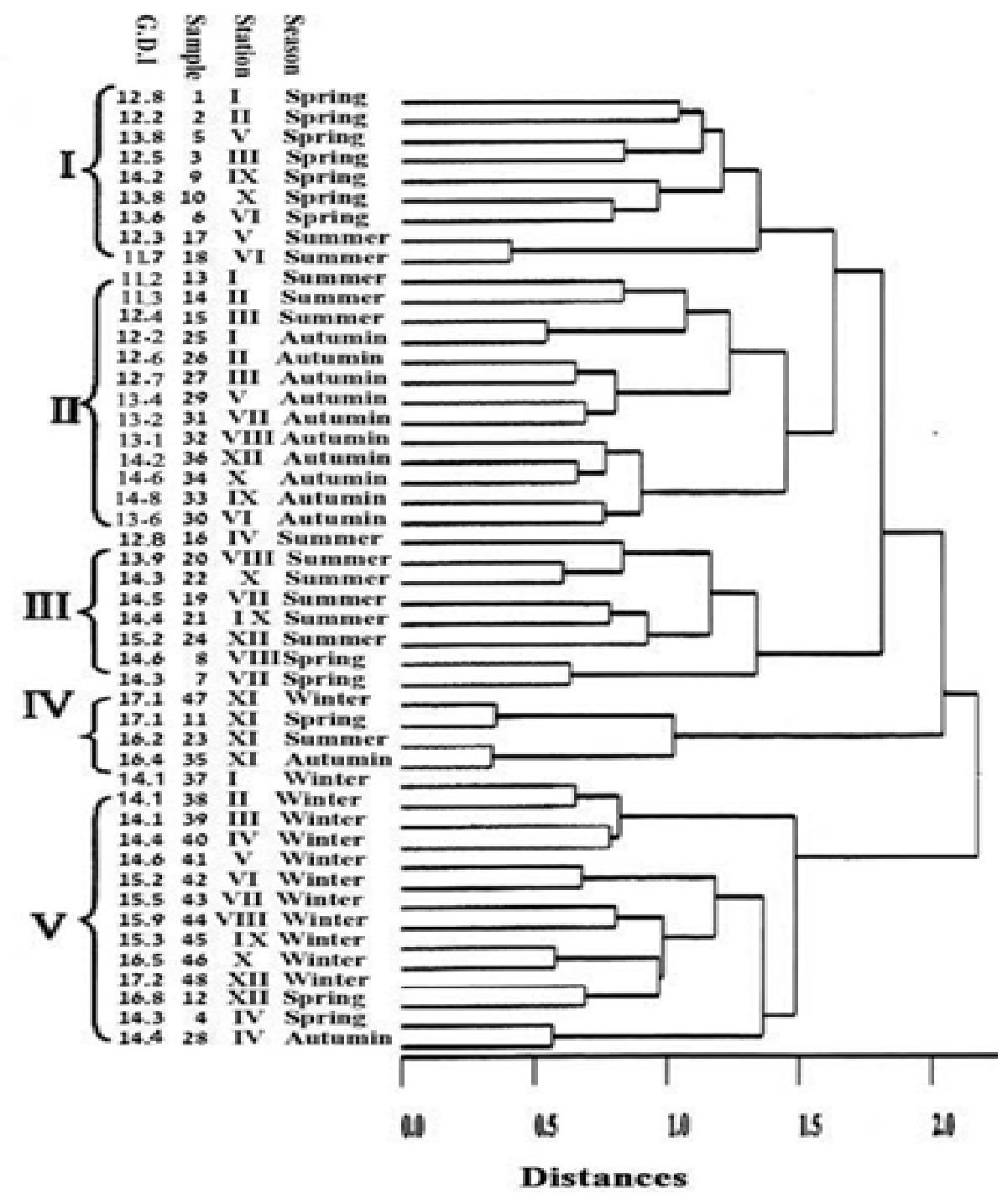

Figure (6): A dendrogram resulted from clustering of the diatom communities, in the different seasons; (also Generic diatom index (GDI) values at each samples are showing). 
This cluster dominated by the species with high abundance e.g: Diatoma vulgare, Cymbella gracilis, Cocconeis pediculus, Amphora protus, Navicula incerta, Gyrosegma spenceri, Melosira distans, Licmophora ehrenbergii and $L$. communis.

The samples of cluster (1) were located at relatively low position along the gradients of chloride, total Phosphorus, salinity, temperature, dissolved organic nitrogen, BOD and silica, and at high position along the gradients of total alkalinity, ammonia, nitrate and dissolved oxygen (Fig. 7). These results are in accordance with that obtained by Polat and Isik (2002) who reported that, ammonia and nitrate enhance the growth rate of algae and acting as available source of nitrogen for algal species.

Samples of cluster (II) were meanly collected in autumn and from different sites (Fig.6). and characterized by the diatom species as Licmophora communis, L. paradoxa Melosira distans, Cymbella tumidula, Achnanthes affinis, A. breviees, Amphora holstica, A. veneta, Cocconeis disculus, C. pediculus, Cyclotella comta, C. melosiroides, Diatoma elongatum, Nitzschia longissima, Fragilaria capucina, F. crotonensis, F. bicapitat Melosira islandica, Synedra ulna, Navicula microcephala, $N$. incerta and $N$. distans. The samples of this cluster were located at low position along the gradients of total phosphorus, $\mathrm{pH}$, silica, sodium, chloride, salinity, temperature, and nitrite, and at high position along the gradients of nitrate, BOD and ammonia (Fig.7). These results are in accordance with that obtained by Anton et al. (1996) and Madkour (2000).

Samples of Cluster (III) mostly collected in Summer and dominated by Amphora veneta, Cyclotella commensis, Navicula inflexa, N. fluens, Achnanthes brevipes, Caloneis bacillum, Diatoma elongatum, Synedra ulna,S. minuscule, S. tabulata, Eunotia lunaris, Fragilaria crotonensis, F. bicapitat Melosira hyperborean, Nitzschia acicularis and Licmophora tenius. These samples were located at high position along the gradients of nitrite, temperature, nitrate, salinity, chloride, $\mathrm{pH}$ and total phosphorus, and are located at low position along the gradients of total alkalinity, BOD and ammonia. These results are in agreement with that obtained by Polat and Isik (2002) and Cook (2007).

Samples of Cluster (IV) were segregated according to the site, and collected from El-Sharm site through the four seasons of the year. This cluster dominated by the epiphytic diatom species Synedra ulna, Melosira undulata, Navicula auglica and Fragilaria capucina. These samples were located at high position along the gradients of $\mathrm{pH}$, total phosphorus, chloride and dissolved oxygen, and at low position along the gradients of salinity, temperature, nitrite, nitrate, DON, potassium and total alkalinity. These results are in accordance to that obtained by Dillon and Rigler (1974), Kuwana et al. (1998) and Lai and Wang (2010).

Samples of cluster (V) were meanly collected in winter season, and were characterized by the diatom species as Melosira distans, Navicula fluens, 
Diatoma elongatum, synedra cycedopum, Nitzshia closterium, Fragilaria intermedia, Eunotia revolute, cylmbella tumidula, cocconies thumensis, Achnanthes affinis and Cocconeis thumensis. The samples of this cluster were located at low position along the gradients of silica, total phosphorus, chloride, sodium, $\mathrm{pH}$ and salinity, and at high position along the gradients of nitrate, potassium, DON, nitrite and temperature. Multivariate analysis has proved useful method to evaluate information on interaction between the epiphytic diatom and its environment.

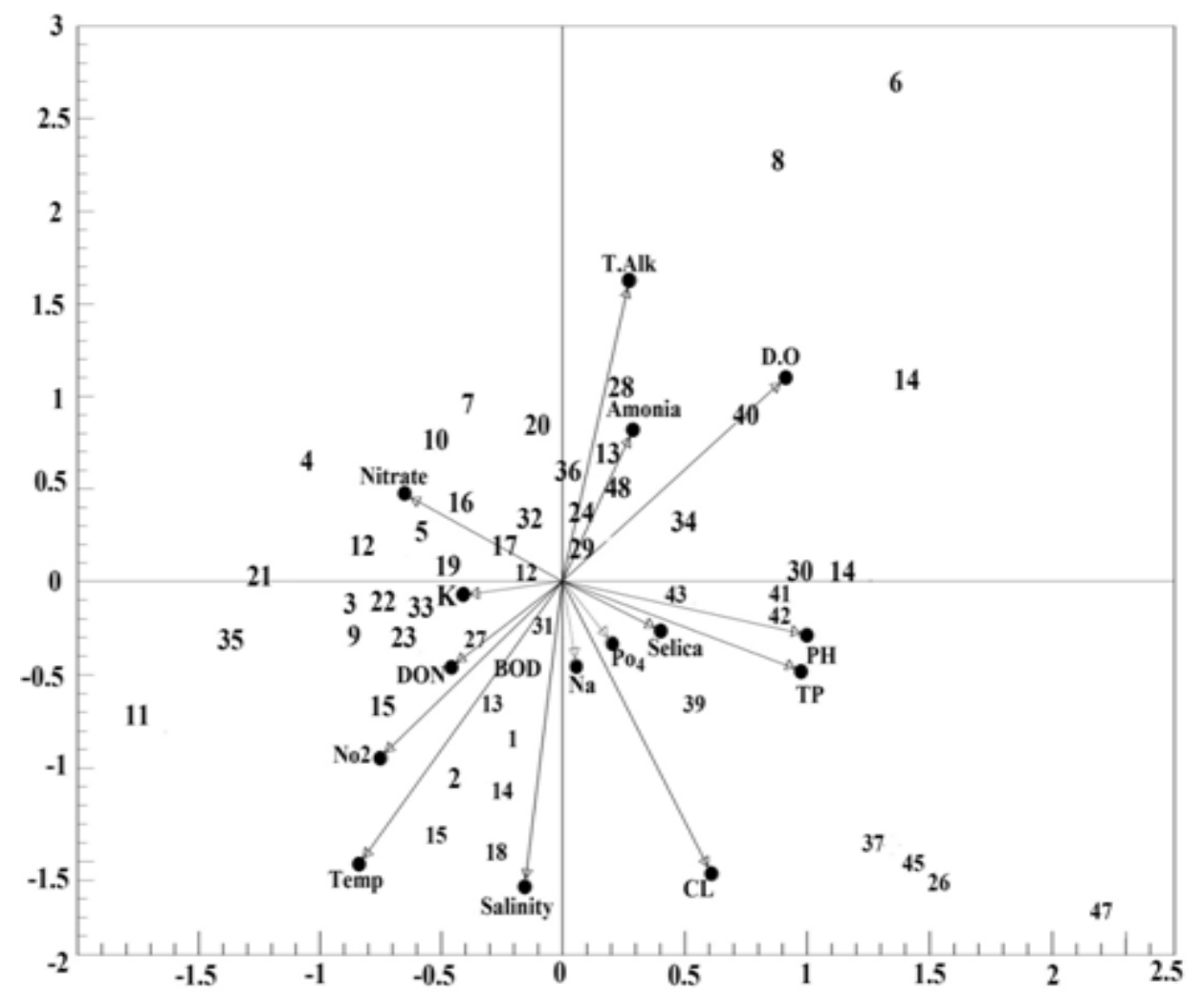

Figure (7): Canonical Correspondence Analysis (CCA) ordination diagram with 48 of epiphytic diatoms samples (cross) along the gradient of water, variables (arrows) in the study area.

The Generic Diatoms Index (GDI) shows that trophic status of sea water, decreased downward from Quantra to Marsa-Alam site seasonally it increased during summer the most samples of cluster I and cluster II were oligomesotrophic water (GDI 12.4 - 13.8) during spring and autumn. Meanwhile during summer same samples $(18,13,16)$ of cluster I and cluster II were mesoeutrophic water (GDI 11.2-12.0). May be due to sewage discharge at Ras-Ghareib and the highest activity of agriculture drainage station at Suez Canal during 
summer (warm season) which results of relative decrease of water salinity and increase of nutrient contents of water especially N, P and Si. Cluster IV, V and most samples of cluster III contained oligotrophic water (GDI $\geq 14$ ) especially during winter season. This is could be attributed to low human impact on the Red Sea coast at these sites and the relative high salinity.In this regard, Lai and Wang (2010) reported that: Salinity and nutrients source of nitrogen, phosphate and silicon were the important factors that impact the growth of epiphytic diatoms .

\section{References}

Abdel-Baky, J. M. (2001). Effect of some wastes on the algal biodiversity in the delta region of the River Nile, M. Sc. Thesis, Bot. Dept., Mansoura Univ. Egypt, pp 377.

Abou- Aisha, K H. M.; Kobbia, I. A.; EL- Abyad, M. S.; Shabana, E. F. and Schanz, F. (1995). Impact of phosphorus loading on macroalgal communities in the Red Sea coast of Egypt. Water, Air, Soil Pollution, 83: 285-297.

Adams, V. (1990). "Water and wastewater examination manual". Lewis publishers, USA, pp. 247.

Adesalu, T. A.; Abiola, T. O. and Bofia, T.O. (2008). Studies on the Epiphytic Algae Associated with Two Floating Aquatic Macrophytes in a sluggish Non- Tidal Polluted Creek in Lagos, Nigeria. Asian J. Sci. Res., 1: 363373.

Anna, W.; Evelyn, G.; Laurel, C.; Thomas, F. and Joseph, B. (2010). Distribution of diatoms and Development of diatom-Based Models for inferring Salinity and nutrients concentrations in Florida Bay and Adjacent Coastal Wetlands of South Florida (USA). J. Estuaries and Coasts, 33:1080-1098.

Anton, R. H.; Robert, L. and Thompson, J. R. (1996). The influence of a dissolved inorganic-N-gradient on phytoplankton community dynamics in a chain of lakes. Hydrobiol., 319: 225-235.

Clifford, H. T. and Stephenson, W. (1975). An introduction to numerical classification. Academic Press, London, 229p.

Cook, G. (2007). Benthic diatoms in the Salinas of the Dry Creek salt fields, South Australia. Hydrobiol., 576 (1): 61-68.

Coste, M. and Ayphassorho, H. (1991). Etude de la qualité des eaux du Bassin Artois-Picardie à l'aide des communautés de diatomées benthiques (Application des indices diatomiques). Raport Cemagref. Bordeaux Agence de l'Eau Artois- Picardie, Douai: 277 pp.

Cronberg, G. (1982). Phytoplankton changes in Lake Trumen induced by restoration. in: Long- term Wade- Lake studies and food- web experiments. Folia Limnologica Scandinavica, 18: 1-119. 
Cupp, E. E. (1943). Marine plankton diatoms of the west coast of North America. Bull. Scripps. Inst. Oceanogr. 5:1-238.

Dillon, P. J. and Rigler, F. H. (1974). The phophorus-Chlorophyll relationship in lakes. Limnol. Oceanogr., 19:767-773.

Durai, K. and Pandiyan, G. (2011). Method for the isolation of epiphytic algae. Int. J. Curr. Sci., 1: 107-108.

Elisabeth, M. G.; Claudia, F. and Andrea, G. (2003). Epiphyte biomass and elemental composition on submersed macrophytes in shallow eutrophic lakes. Hydrobiol., 509 : 559-565.

EPA (1983). "Methods for Chemical Analysis of Water and Wastes". U.S. Environ. Protec. Agency, EPA-690/4-79-020, Cincinnati, OH, USA.

Fatam, C. and Tufan, K. (2010). Tour new record for the benthic diatoms from the Aegean Sea. Turk. J. Bot., 34: 118-128.

Ganf, G. G. (1974). Diurnal mixing and vertical distribution of phytoplankton in a shallow equatorial lake (Lake George, Uganda). J. Ecol., 62: 611-629.

Gordon, N.; Adams, J. B. and Bate, G. C. (2007): Epiphytes of the St. Lucia Estuary and their response to water level and salinity changes during a severe drought. Aquatic Bot., 88: 66 - 76.

Hassan, F. M.; Hadi, R. A.; Kassim, T. I. and Hassany, S. Al. (2012). Systematic study of epiphytic algal after restoration of Hawizah marshes, southern of Iraq. International Journal of Aquatic Science, 3(1):37-57.

Head, S. M. (1987). Corals and coral reefs of the Red Sea; in A. J. Edwards and S. M. Head (eds.), Red Sea (Key environments), Pergamon Press, Oxford,Pp128- 151.

Janina, K.; Pertti, E.; Barbara, K. and Krzysztof, W. (1998). Use of benthic diatom communities to evaluate water quality in rivers of southern Poland. Journal of Applied Phycology, 10: 193-201.

Juttner, I.; James, P. C. and Steve, J. O. (2010). Using diatoms as quality indicators for a newly-formed Urban Lake and its Catchment Environ. Monit Assess., 162: 47-65.

Katoh, K. (1991). Diatom assemblages in a high moor: an observed correlation between species composition and pool size. Japan Journal of Phycology, 39:363-368.

Krammer, K. and Lange-Bertalot, H. (1986-1991). Bacillariophyceae Parts 1-4. Volume 2 of "Süsswasserflora von Mitteleuropa", edited by Ettl, H. et al. Gustav Fischer Verlag, Stuttgart, Germany. 1-4.

Kuwana, K.; Matsuka, S.; Kono, S.; Ninomiya, M.; Onishi, J. and Saga, N. (1998). Growth and the content of laurenterol and debromolaurinterol in Laurencia okamurae (Ceramiales, Rhodophyta). J. Applied Phycol., 10: 9-14. 
Lai, S. D. and Wang, J. (2010). Multivariate analysis of dominant attached diatoms and water quality in Szu-Tsao-Taiwan. J. Diatom, 20: 133-143.

Lecointe, C.; Coste, M. and Prygiel, J. (1993). OMNIDIA': software for taxonomy, calculation of diatom indices and inventories management. Hydrobiol., 296/270:509-513.

Lesley, P. B.; Kenneth, L. H.; Thomas, A. F.; Anna, R. A. and James, W. F. (2010). Nutrient enrichment, grazer identity, and their effects on epiphytic algal assemblages: field experiments in subtropical turtle grass Thalassia testudinum meadows. Marine Ecology Progress Series, 406:33-45.

Madkour, F. F. (2000). Ecological studies on the phytoplankton of the Suez Canal, Ph. D. thesis, Bot. Dept, Suez Canal Univ., Egypt, pp211.

Person, T. R. and Strickland, J. D. (1965): A practical handbook of seawater analysis. Bull. Fish. Res. Bd. Can., 167pp.

Poisson, A.; Morcos, S.; Souvermezoglou, E. and Ivanoff, A. (1984): Some aspects biogeochemical cycles in the Red Sea with special reference to new observations made in summer 1982. Deep Sea Res., 31: 707-718.

Polat, S. and Isik, O. (2002). Phytoplankton distribution, diversity and nutrients at the north- eastern Mediterranean coast of Turkey (Karatas- Adana). Turk. J. Bot., 26: 77- 86.

Ter Braak, C. J. F. (1987): The analysis of vegetation - environment relationships by Canonical Correspondence Analysis (CCA). Vegetatio, 69: 69-77.

Tiina, N.; Helen, L. and Tõnu, F. (2010). Primary production of aquatic macrophytes and their epiphytes in two shallow lakes (Peipsi and Võrtsjärv) in Estonia. Aquat. Ecol., 44:83-92.

Trono, G. C. Jr. and Tolentino, G. L. (1992). The reproductive phenology of Sargassum species (Fucales, Phaeophyta) in Bolinao, Pangasinan. In: Calumpong, H. P., Meñez E. G., editors, Proc. 2nd Rp-USA Phycology Symp. Workshop. Los Banos, Laguna, Philippines: Philippine Council for Aquatic and Marine Research and Development, p.181-193.

Vis, C.; Hudon, C. and Carignan, R. (2006). Influence of the vertical structure of macrophyte stands on epiphyte community metabolism. Fisheries and Aquatic Sciences, 63 (5): 1014-1026. 


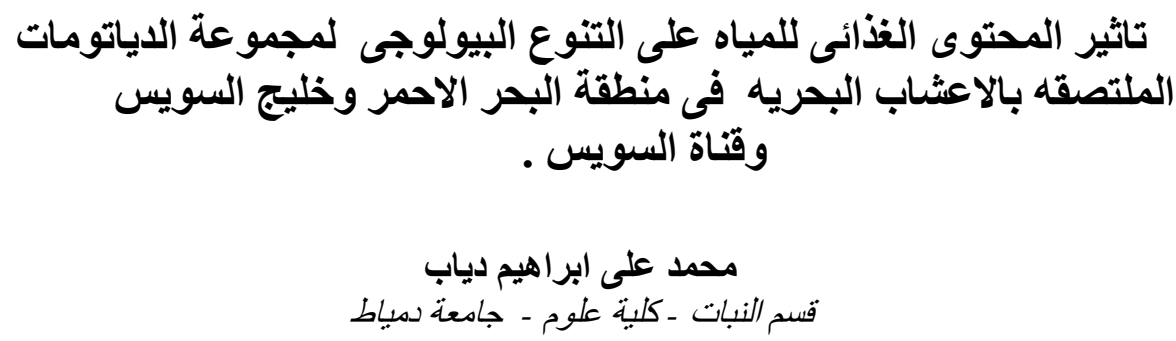

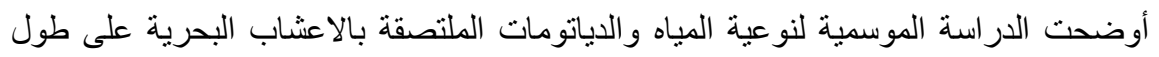

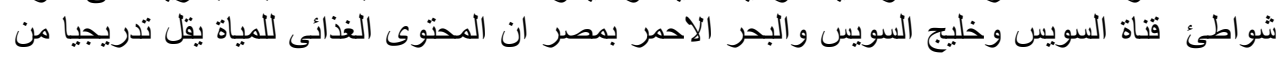

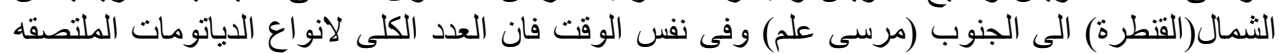

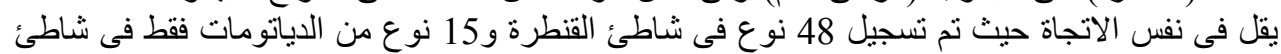

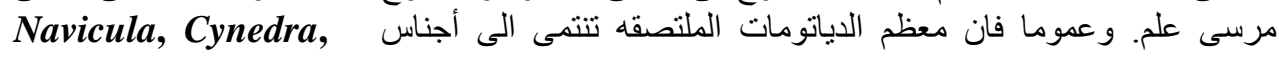
Achnanthes, Eunotia, Diatoma, Cocconeis Cymbella, Licmophora, fragilaria, Amphora and Melosira

بالنسبه للنموات العاليه للاياتومات على مستوى العدد الكلى او الكتله الحيه فقد نم تسجيله خلال

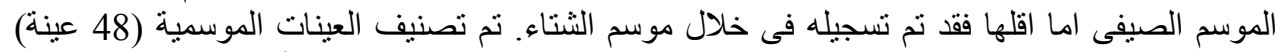

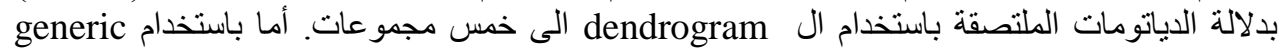
diatom index

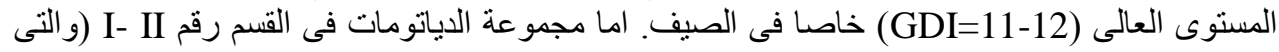

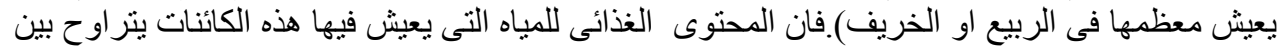

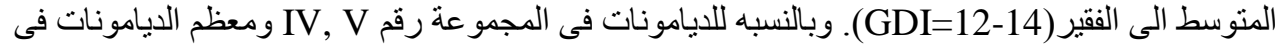

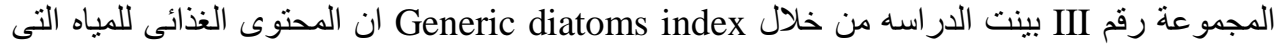

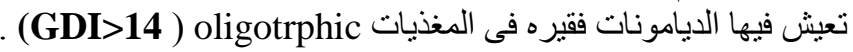

